\title{
Finfish Juvenile Destruction in and around the World Heritage Site of Indian Sundarbans and Possible Mitigative Steps
}

\author{
Abhijit Mitra ${ }^{1 *}$, Goutam Roy Chowdhury ${ }^{2}$ and Tanmay Ray Chaudhuri ${ }^{3}$ \\ ${ }^{1}$ Department of Marine Science, University of Calcutta, India \\ ${ }^{2}$ Chancellor, Techno India University, India \\ ${ }^{3}$ Department of Oceanography, Techno India University, India
}

Submission: March 01, 2017; Published: March 07, 2017

*Corresponding author: Abhijit Mitra, Department of Marine Science, University of Calcutta, 35, BC. Road, Kolkata- 700 019, India, Tel: +919831269550; Email: abhijit_mitra@hotmail.com

\begin{abstract}
West Bengal is a maritime state in the northeast part of the Indian sub-continent adjacent to Bangladesh, which has a coastal area of 10,158.22 sq. km. The coastal zone encompasses the famous mangrove ecosystem of Indian Sundarbans, which can be divided into various transects on the basis of salinity. The practice of wild harvest of tiger prawn seeds in the present geographical locale is the greatest ecological threat in terms of magnitude as a large variety of fish juveniles are damaged during the screening process. The present paper deals with the finfish juvenile count and diversity in three different salinity regimes of the coastal ecosystem with particular emphasis on their spatial and temporal variations for a span of ten years (January, 2007 to December, 2016). This data bank has been generated from the wasted finfish juvenile samples that are thrown away after collection and subsequent segregation of tiger prawn seeds from the coastal waters. The ten years data revealed a sequential uniformity in all the selected stations, the diversity being maximum in the high saline zone and minimum in the upper stretch of the estuary where the salinity of the aquatic phase is lowest (almost zero psu in monsoon). Some conservation measures, in the form of alternative livelihood schemes have also been suggested at the end which can divert the tiger prawn seed collectors from this destructive practice leading to a conservation of fish germplasm in and around the World Heritage Site of Indian Sundarbans mangrove ecosystem.
\end{abstract}

\section{Introduction}

Ichthyoplankton and fish juveniles are the major biotic components of the world ocean [1] and play a vital role in regulating the marine food chain. They are widely distributed in the brackish water system and mangrove dominated coastal zone owing to the presence of mangrove vegetation derived nutrients and congenial environmental conditions for their growth and survival. It is reported that the mangrove ecosystem serves as the nursery of a large spectrum of fish juveniles [25]. This unique ecosystem forms an ideal ecological reservoir for the pelagic community because the production of leaf litter and detrital matter from mangrove plants fulfills the nutritional requirements of prawn juveniles, crab megalops and juveniles of several species of osteichthyes. Due to this fact, the mangrove ecosystem is recognized as the world's most potential nursery and breeding ground [5].

The Indian Sundarbans lie at the apex of the Bay of Bengal and sustain the famous mangrove ecosystem of the Tropics.
The islands and the associated waters, creeks and estuaries of the deltaic lobe are the nurseries for many coastal and oceanic species of fish that support commercial fisheries in the northern Bay of Bengal. The diverse vegetation of the Sundarbans forests includes about 34 true mangrove species that provide a unique mix of habitats for wildlife, which includes tiger, deer, wild boar, monkey, turtles, terrapins, dolphins, estuarine crocodiles and several species of birds, many of which are migratory. This region is considered as one of the most backward regions in the maritime state of West Bengal and is home to about 4.2 million people, of whom $56 \%$ are landless. Literacy rates are below $35 \%$ most communities do not have electricity or safe drinking water and agricultural productivity is lower than the state average. Inadequate infrastructure, poor communication facilities, lack of access to clean drinking water, health and education services and a fragile and limited natural resource base have contributed to a low level of development and high poverty incidence in the region. 
A diminishing natural resource base is threatening the ecological integrity of Indian Sundarbans and the livelihood of the inhabitants. At present, the major environmental-cum-socioeconomic issue in this mangrove ecosystem is the proliferation of the shrimp farms. In the absence of any hatchery in the entire state, the supply of tiger prawn seeds to these farms is done through the wild collection from the estuarine and coastal waters. Thousands of women and children collect wild tiger prawn seeds by employing nets of a particular mesh size to haul in the drifting community, irrespective of the tides, and throw away the major portion of the haul (containing the juveniles of finfish and shellfish) after sorting out the post larvae (or seeds) of tiger prawn. This practice results in a great loss of pelagic biodiversity (in terms of stock) which might cause an adverse effect on the delicate ecological balance of the system $[7,11]$. A negative impact also becomes obvious in the prospect of demersal fisheries of the state of West Bengal due to this indiscriminate destruction of the various species of fishes at their juvenile stages. With this background, the present paper aims to highlight the magnitude of finfish juvenile diversity loss in different seasons of the year during 2007-2016. This occupation has spread its root to such an extent that about $95 \%$ of the coastal population living below poverty line is engaged with this destructive activity. It is very difficult to implement a total ban on this activity, as these huge masses will face extreme economic marginalization. So, our present paper suggests few alternative livelihood schemes, which may establish a harmony between the biological diversity and socio-economic profile of the area.

\section{Description of the Study Area}

West Bengal is a maritime state in the northeast part of the Indian sub-continent adjacent to Bangladesh. The coastal zone of this state spreads over an area of $10,158.22 \mathrm{sq} . \mathrm{km}$. and is restricted within the latitude $21^{\circ} 30 / \mathrm{N}$ to $22^{\circ} 30 / \mathrm{N}$ and longitude $87^{\circ} 25 / \mathrm{E}$ to $89^{\circ} 10 / \mathrm{E}$. The River Harinbari or Heronbhanga of the Indian Sundarbans (India- Bangladesh border) is the eastern most borders while the New Digha coast of Orissa-West Bengal border constitutes the western boundary of coastal West Bengal. With considerable degree of marine characteristics in the major portion of the ecosystem, the important morphotypes of coastal West Bengal are sandflats, coastal dunes, beaches, mudflats, estuaries, creeks, inlets and mangrove flats. There is a drastic variation of salinity and dilution factor between different horizontal transects of the ecosystem. The dilution factor, salinity and $\mathrm{pH}$ reveal significant variations at the same time in different locations of the coastal zone [8]. The recent emergence of Haldia industrial complex and various fish landing stations in the coastal zone has also opened the gateway of input of various categories of wastes in this ecosystem.

Geographically, the study area encompasses three major districts of the state of West Bengal namely, 24 Parganas (North), 24 Parganas (South) and Medinipur (East). The Indian
Sundarbans, which has been declared as the World Heritage Site by UNESCO in the year of 1989 fall within the North and South 24 Parganas districts. Three sampling stations were selected in and around this deltaic ecosystem namely, Diamond Harbour (station 1), Sagar light house (station 2) and Junput (station 3). Each of these sampling stations is markedly different from the other with respect to aquatic salinity due to their location and proximity to the Bay of Bengal.

Diamond Harbour (station 1) is situated in the low saline upper stretch of Hooghly estuary, just outside the northern boundary of Indian Sundarbans. The station is very near to the Haldia port-cum-industrial complex. Salinity of surface water is minimum around the station owing to its location far away from the Bay of Bengal in the extreme upstream region and also due to huge fresh water discharge from the Hooghly River, which is perennial in nature. The station has three mangrove species along with few mangrove associates like Porteratia coarctata (salt marsh grass) and seaweeds (Enteromorpha sp.).

Sagar light house (station 2) is situated in the south western tip of the Sagar Island and falls in the western sector of Indian Sundarbans. The station has rich mangrove vegetation and extensive mudflats. Although there are no industrial activities in this station, but the presence of sizeable number of shrimp farms (presently carrying on shrimp culture by traditional method with a very low stocking density of prawn seeds) has enriched the surrounding water with nutrients and organic load.

Junput (Station 3) is situated in the Medinipur (East) district of coastal West Bengal, which is noted for its high aquatic salinity owing to its proximity to the Bay of Bengal. The extremely high salinity has posed an inhibitory effect on the growth and survival of mangroves in this station [9]. Existence of saltpans has made the soil of the area hyper saline in nature. Although the station has no industry around its vicinity, but the presence of Digha tourist center and Shankarpur fishing harbour close to the station has multiplied the anthropogenic pressure around the zone.

In all these stations, tiger prawn seeds collection is a very common scene in which the coastal and estuarine waters are screened in search of target species (seeds of Penaeus monodon) by using nets of very fine mesh size. This activity traps a varied spectrum of several finfish juveniles (non-target species), which are subsequently thrown away and destroyed.

\section{Materials and Methods}

Finfish juvenile samples were collected monthly during January 2007 to December 2016 from tiger prawn seed collectors. Collections of 10 nets were randomly mixed and a constant weight of $10 \mathrm{gm}$ was preserved in $4 \%$ formaldehyde. The samples were identified from Zoological Survey of India and its count was done using hand lens. Triplicate counts were done to reach the maximum accuracy level and the mean 
value of the species count was finally used to enumerate the community structure of finfish juvenile in the study area through computation of Shannon Weiner Species Diversity Index [10]

\section{Results and Discussion}

\section{Root cause of tiger prawn seed collection}

Mushrooming of shrimp culture activities: The aquatic sub-subsystem of coastal West Bengal is highly congenial for the culture of tiger prawn not only because of the aquatic salinity, tidal flushing (which favours the process of water exchange), but also because of the rich phytoplankton diversity (102 species documented so far) in the optimum level of aquatic nutrients [11]. About 33000 ha in North 24 Parganas and 12000 ha in South 24 Parganas districts have been devoted for shrimp culture activities, which have high demand for tiger prawn seeds for economic viability. This demand is mitigated through wild harvest of PL20 (larval stage 20 days from the hatching date) from estuaries, coastal wetland and brackish water creeks [12$14]$.

Absence of hatchery: Currently, there are few operational shrimp nurseries in West Bengal, but no ideal hatchery in real sense (i.e. spawning of adult to produce nauplii). Low salinity is the biggest problem for shrimp hatchery in West Bengal coast, particularly in Sundarbans. In the absence of any hatchery, the demand for tiger prawn seeds has become very acute and the entrepreneurs have no option, but to depend on wild harvest of tiger prawn seeds.

Socio-economic profile: The socio-economic profile of coastal West Bengal is not very encouraging, particularly, in Indian Sundarbans, it is highly distressed. Recently, the population has touched the figure of 4.2 million, which is predominated by farming and fishing community. More than $90 \%$ of the farming community is either small or marginal farmers and about $50 \%$ survives below the poverty level. This sizable chunk of population engages themselves in screening the estuarine water from dawn to dusk in search of the target species which brings immediate cash to them. The price of tiger prawn seeds ranges from Rs. 200 per 1000 to Rs. 800 per 1000 depending on the season and demand [15].

\section{Community structure of finfish juvenile}

The coastal zone of West Bengal is one of the most biologically productive, taxonomically diverse and aesthetically celebrated ecotone of the country, which is sustaining the famous mangrove ecosystem of Indian Sundarbans [16]. The pelagic system around the coastal zone is highly productive due to considerable concentrations of nutrients derived from anthropogenic origin, run-off from the adjacent landmasses, litters and detritus of mangrove vegetation, etc.

Table 1: Monthly average Standing Stock $(\mathrm{N})$ and Shannon-Weiner Species Diversity Index of finfish juvenile species $(\mathrm{H})$ of three selected sampling stations during Jan 2007 to Dec 2016.

\begin{tabular}{|c|c|c|c|c|c|c|c|c|c|c|c|c|c|c|c|c|c|c|}
\hline \multirow{3}{*}{ Year } & \multicolumn{9}{|c|}{ Mean Standing Stock (N) of Finfish Species } & \multicolumn{9}{|c|}{$\begin{array}{c}\text { Mean Shannon-Weiner Species Diversity Index of Finfish } \\
\text { Species (H) }\end{array}$} \\
\hline & \multicolumn{3}{|c|}{ Stn 1} & \multicolumn{3}{|c|}{ Stn2 } & \multicolumn{3}{|c|}{ Stn3 } & \multicolumn{3}{|c|}{ Stn1 } & \multicolumn{3}{|c|}{ Stn2 } & \multicolumn{3}{|c|}{ Stn3 } \\
\hline & Prm & Mon & Pom & Prm & Mon & Pom & Prm & Mon & Pom & Prm & Mon & Pom & Prm & Mon & Pom & Prm & Mon & Pom \\
\hline 2007 & 392 & 161 & 245 & 1598 & 134 & 522 & 1593 & 260 & 767 & 2.915 & 2.299 & 2.78 & 3.529 & 1.748 & 3.011 & 3.483 & 2.286 & 3.263 \\
\hline 2008 & 321 & 133 & 291 & 1315 & 122 & 422 & 1303 & 213 & 625 & 2.917 & 2.301 & 2.779 & 3.529 & 1.555 & 3.008 & 3.482 & 2.279 & 3.266 \\
\hline 2009 & 200 & 82 & 183 & 1273 & 99 & 416 & 1290 & 213 & 631 & 2.894 & 2.271 & 2.767 & 3.529 & 1.618 & 3.018 & 3.484 & 2.289 & 3.278 \\
\hline 2010 & 195 & 79 & 175 & 1279 & 99 & 413 & 1229 & 201 & 596 & 2.881 & 2.244 & 2.736 & 3.509 & 1.599 & 3.037 & 3.479 & 2.294 & 3.278 \\
\hline 2011 & 215 & 89 & 197 & 1090 & 84 & 361 & 1055 & 172 & 651 & 2.928 & 2.327 & 2.814 & 3.527 & 1.497 & 3.027 & 3.481 & 2.297 & 3.28 \\
\hline 2012 & 217 & 89 & 198 & 716 & 56 & 233 & 679 & 123 & 333 & 2.929 & 2.326 & 2.805 & 3.523 & 1.625 & 3.043 & 3.461 & 2.284 & 3.287 \\
\hline 2013 & 224 & 93 & 204 & 639 & 51 & 209 & 601 & 103 & 291 & 2.919 & 2.307 & 2.791 & 3.535 & 1.637 & 3.042 & 3.464 & 2.293 & 3.25 \\
\hline 2014 & 221 & 92 & 201 & 545 & 42 & 180 & 521 & 89 & 255 & 2.925 & 2.309 & 2.797 & 3.541 & 1.602 & 3.033 & 3.484 & 2.302 & 3.292 \\
\hline 2015 & 225 & 93 & 204 & 910 & 178 & 442 & 934 & 153 & 440 & 2.931 & 2.307 & 2.791 & 3.405 & 2.509 & 3.156 & 3.498 & 2.207 & 3.304 \\
\hline 2016 & 389 & 38 & 67 & 936 & 73 & 304 & 1020 & 79 & 367 & 2.868 & 1.48 & 1.969 & 3.531 & 1.608 & 3.03 & 3.427 & 1.84 & 3.091 \\
\hline
\end{tabular}

stations during Jan 2007 to Dec 2016.

'Stn' refers to Station.

'Prm' refers to Pre monsoon.

'Mon' refers to Monsoon.

'Pom' refers to Post monsoon. 


\section{Fisheries and Oceanography Open Access Journal}

Table 1 exhibits the monthly average of Standing Stock (N) and Shannon Weiner Species Diversity Index (H) of finfish juvenile species in the three sampling stations. Members of genus Coilia sp., Thryssa sp., Mugil sp., Tenualosa sp., Liza sp., Scatophagus sp., Stolephorus sp., Cynoglossus sp., Sillago sp. are dominant (in terms of standing stock or biomass) in all the stations (Table 2) and in all the months of the study period, which suggests the wide range of tolerance of this genus in the present geographical locale. The study clearly depicts the regulation of finfish juveniles by aquatic salinity. Similar observations were also recorded by earlier workers in this study area $[8,17-$ 20]. The regulatory role of salinity on finfish juvenile species composition and abundance was also confirmed in a South African case study [21]. The diversity of finfish juvenile is highest at station 3 (Junput) which is followed by station 2 (Sagar light

Table 2: Distribution of finfish juvenile species in 10 gm composite wasted sample collected from three selected sampling stations during Jan 2007 to Dec 2016

\begin{tabular}{|c|c|c|c|c|}
\hline Sl. No & Species & Station 1 & Station 2 & Station 3 \\
\hline 1 & Coilia sp. & + & + & + \\
\hline 2 & Thryssa hamiltonii (Gray) & + & + & + \\
\hline 3 & Thryssa baelama & + & + & + \\
\hline 4 & Torquigener oblongus & + & + & + \\
\hline 5 & Rhinomugil corsula & + & + & + \\
\hline 6 & Mugil cephalus & + & + & + \\
\hline 7 & Sillaginopsis panijus & + & + & + \\
\hline 8 & Sillago sihama & + & + & + \\
\hline 9 & Sillago soringa & + & + & + \\
\hline 10 & Zenarchopterus dispar & + & + & + \\
\hline 11 & Glossogobius quiris & + & + & + \\
\hline 12 & Pseudapocryptes lanceolatus & + & + & + \\
\hline 13 & Eupleurogrammus glossodon & + & + & + \\
\hline 14 & Pseudorhombus sp. & + & + & + \\
\hline 15 & Pisodonophis boro & + & + & + \\
\hline 16 & Tenualosa ilisha & + & + & + \\
\hline 17 & Cynoglossus arel & + & + & + \\
\hline 18 & Cynoglossus sp. & + & + & + \\
\hline 19 & Leiognathus blochii. & - & + & + \\
\hline 20 & Leiognathus equalus & + & + & + \\
\hline 21 & Hilsa sp. & + & + & + \\
\hline 22 & Scatophagus argus & + & + & + \\
\hline 23 & Liza parsia & + & + & + \\
\hline 24 & Liza tade & + & + & + \\
\hline 25 & Stolephorus commersonii & + & + & + \\
\hline 26 & Stolephorus baganensis & + & + & + \\
\hline 27 & Stolephorus kammalensis & + & + & + \\
\hline 28 & Lutjanus johni & + & + & + \\
\hline 29 & Setipinna taty & + & + & + \\
\hline 30 & Lagocephalus lunaris & - & + & + \\
\hline
\end{tabular}


Fisheries and Oceanography Open Access Journal

\begin{tabular}{|l|c|c|c|c|}
\hline 31 & Escualosa thoracata & - & + & + \\
\hline 32 & Epinephelus tauvina & - & + & + \\
\hline 33 & Epinephelus coioides & - & + & + \\
\hline 34 & Sphyraena sp. & - & + & + \\
\hline 35 & Pomadasys sp. & - & + & + \\
\hline 36 & Sardinella longiceps & - & + & + \\
\hline 37 & Periophthalmus sp. & - & + & + \\
\hline 38 & Macrognathus sp. & - & + & + \\
\hline 39 & Tetradon cutcutia & - & + & + \\
\hline 40 & Bregmaceros meclellandii & - & + & + \\
\hline 41 & Ichthyocampus carce & - & + & + \\
\hline 42 & Stigmatogobius sp. & - & + & + \\
\hline 43 & Channa sp. & - & + & + \\
\hline 44 & Kurtus indicus & - & + & + \\
\hline 45 & Harpodon nehereus & - & + & + \\
\hline 46 & Moringua raitaborua & Suggrundus rodricensis & + & + \\
\hline 47 & & - & + & + \\
\hline
\end{tabular}

\section{Conservation measures}

The wasted juvenile species of osteichthyes have considerable total economic value and hence the destructive operation rate needs an immediate retardation through few suggestive measures as pinpointed below:

a.Development of alternative livelihood (like piggery, campbell culture, kroiler rearing, sewing, apiculture, fish feed manufacturing, handicrafts, spice grinding etc.) to defray the prawn seed collectors from the present destructive operation. Techno India University, West Bengal has developed a pondbased livelihood scheme for people living Below Poverty Line (BPL) of the state.

b.Setting up of tiger prawn seed bank (nursery) in the high saline zone of Sundarbans and linking the same with the hatcheries present in the maritime states of South India like Orissa, Andhra Pradesh and Tamil Nadu.

c.Increase of awareness programme amongst the prawn seed collectors. Several Academic Institutes (like Techno India University, West Bengal) and reputed NGOs of the state have initiated this task through several projects financed by Ministry of Environment \& Forests, Govt. of India, Dept. of Science \& Technology, Govt. of India, Dept. of Environment, Govt. of West Bengal etc.

d.Encouraging the people for canal excavation to harvest the rain water which can help to develop the second cropping during summer season. Four canals have already been excavated in the Chotomollakhali islands of Indian Sundarbans with the funding and assistance of WWF-India and mono-cropping pattern in the zone has been replaced by multiple cropping systems.
e.Promotion and subsequent scaling up of non-conventional pilot projects like seaweed culture, oyster culture, ornamental fishery, mono-sex tilapia culture, biofertilizer preparation etc. to broaden the avenue of alternative livelihood for future.

Again, a new concept of conservation is soon going to crystallize in the Indian Sundarbans regions in the form of 'Rural Technology Park'. In this unit, apart from awareness generation programme through adult education, some experimental ponds will be designed to monitor the survival rate of fish juveniles which are thrown away and wasted during wild tiger prawn seed collection. It is expected that such approach may reduce the mortality percentage of fish species in their juvenile stage [23].

\section{References}

1. Verlecar XN, Parulekar AH (2001) Primary Productivity. In: Rabin Sengupta, Ehrlich Desa (Eds.), The Indian Ocean- A Perspective. Oxford and IBH Publishers, India, Chapter 10(2): 397-415.

2. Mitra A, Choudhury A, Zamaddar YA (1992) Effects of heavy metals on benthic molluscan communities in Hooghly estuary. Proceedings of the Zoological Society 45: 481-496.

3. Mitra A, Sasmal SK, Choudhury A, Bhattacharyya DP (2000) Seasonal variations of ichthyoplankton in mangrove ecosystem of Indian Sundarbans, Indian Journal of Environment and Ecoplanning 3(3): 535-538.

4. Banerjee K, Mitra A, Bhattacharyya DP, Choudhury A (2002) Role of nutrients on phytoplankton diversity in the northeast coast of the Bay of Bengal. In: Arvind Kumar (Ed.), Ecology and Ethology of Aquatic Biota. Daya Publishing House, New Delhi, India, 102-109.

5. Mitra A, Pal S (2002) In: Col Shakti Banerjee, Farida Tampal (Eds.), The Oscillating Mangrove Ecosystem and the Indian Sundarbans. WWFIndia, West Bengal State Office, India.

6. Trivedi S, Mitra A, Choudhury A, Gupta A, Singh B, et al. (1994) A case study of the loss of Bio-diversity during Prawn Seed Collection from the Hooghly Estuary, India. Proceedings of the National Convention 
of Environment of India- Challenges for the $21^{\text {st }}$ century Institution of Public Health Engineers, India, pp. 16-24.

7. Nagaeswara Rao CA (2004) Faunal Diversity: Estuarine Ecosystem, EPTRI-ENVIS Newsletter, 10(3).

8. Mitra A (2000) The northeast coast of the bay of Bengal and deltaic Sundarbans. In: Charles Sheppard (Edt.), Seas at the MillenniumAn Environmental Evaluation, University of Warwick, U.K., Elsevier Science 143-157.

9. Mitra A, Banerjee K, Bhattacharyya DP (2004) In: The Other Face of Mangroves ( $1^{\text {st }}$ edn), Dept. of Environment, GoWB, India.

10. Shannon CE, Weiner V (1949) In: The Mathematical Theory of Communication. University of Illionis Press, USA, pp. 117.

11. Mitra A, Banerjee K, Gangopadhyay A (2004) In: Introduction to Marine Plankton. Daya Publishing House, New Delhi, India.

12. Banerjee K, Das S, Mitra A, (2005) Temporal loss of ichthyoplankton due to wild harvest of prawn seeds in Indian Sundarbans, Seshiyana, India.

13. Banerjee K, Bhattacharyya DP, Mitra A (2005) Tiger prawn seed catch in coastal waters: Estimation of ichthyoplankton community damage, SIOS, Europe.

14. Mitra A, Banerjee K, Chakraborty R, Banerjee A, Mehta N et al. (2005a) Study on the water quality of the shrimp culture ponds in Indian Sundarbans. Indian Science Cruiser, India.

15. Bhattacharyya DP, Mahapatra B, Banerjee K, Mitra A (2003) Application of Statistics in Marine Biology- a right choice is required, Sea Explorers 6: 13-20.

16. Bhattacharya M, Banerjee K, Roy A, Mitra A, Bhattacharyya DP (1999) Preliminary study on the impact of oil and grease on finfish juveniles around Haldia Port-cum-industrial complex. Journal of the Inland Fisheries Society of India 31(2): 36-38.

17. Mitra A., Niyogi, S, Choudhury A (1998) Impact of wild harvest of prawn seeds on the community structure of juvenile fish in the coastal part of West Bengal. In: Qasim SZ, Roonwal GS (Edt.), Living Resources of India's Exclusive Economic Zone Omega Scientific Publisher, India, 86-96.

18. Niyogi S, Mitra A, Saha S, Choudhury A (1998) Inter-relationship between diversity of prawn juveniles and mangroves in the coastal zone of West Bengal. In: Qasim SZ, Roonwal GS (Eds.), Living Resources of India's Exclusive Economic Zone, Omega Scientific Publisher, India, 97-102.

19. Mitra A, Bhattacharyya DP (2003) Environmental issues of shrimp farming in mangrove ecosystems. Journal of Indian Ocean Studies 11(1).

20. Panja U (2004) Shrimp seed collection and Ecological crop loss in coastal West Bengal, World Environment Day Special, WWF-India, West Bengal, India.

21. Whitfield AK (1999) Ichthyofaunal assemblages in estuaries: A South African case study. Reviews in Fish Biology and Fisheries 9(2): 151186.

22. Mitra A, Banerjee K, Raha AK, Ghosh S, Bhattacharyya DP (2005) Status of shark community in coastal West Bengal. Indian Science Cruiser 19(2): 1-9.

23. Mitra A, Banerjee K (2005) In: Banerjee SR (Ed.), Living Resources of the Seas: Focus Sundarbans, Published by WWF-India, Canning Field Office, West Bengal, India, pp. 96.

\section{Your next submission with Juniper Publishers will reach you the below assets}

- Quality Editorial service

- Swift Peer Review

- Reprints availability

- E-prints Service

- Manuscript Podcast for convenient understanding

- Global attainment for your research

- Manuscript accessibility in different formats

( Pdf, E-pub, Full Text, Audio)

- Unceasing customer service

Track the below URL for one-step submission https://juniperpublishers.com/online-submission.php 